\title{
ACVR1C Gene
}

National Cancer Institute

\section{Source}

National Cancer Institute. ACVR1C Gene. NCI Thesaurus. Code C96019.

This gene plays a role in protein phosphorylation and signal transduction. 